Article

\title{
Extract from the Macroalgae Ulva rigida Induces Table Grapes Resistance to Botrytis cinerea
}

\author{
Alon Shomron ${ }^{1,2}{ }^{\oplus}$, Danielle Duanis-Assaf ${ }^{2,3}$, Ortal Galsurker ${ }^{2}$, Alexander Golberg ${ }^{1, *}$ and Noam Alkan ${ }^{2, *}$ \\ 1 Department of Environmental Studies, Porter School of Environment and Earth Sciences, \\ Faculty of Exact Sciences, Tel Aviv University, Tel Aviv 6997801, Israel; alon.shomron@mail.huji.ac.il \\ 2 Department of Postharvest Science of Fresh Produce, Agricultural Research Organization (ARO), \\ Volcani Center, Rishon LeZion 7505101, Israel; danielle.assaf@mail.huji.ac.il (D.D.-A.); \\ ortalg@volcani.agri.gov.il (O.G.) \\ 3 Robert H. Smith Faculty of Agriculture, Food and Environment, The Hebrew University of Jerusalem, \\ Rehovot 76100, Israel \\ * Correspondence: agolberg@tauex.tau.ac.il (A.G.); noamal@volcani.agri.gov.il (N.A.)
}

check for updates

Citation: Shomron, A.; Duanis-Assaf, D.; Galsurker, O.; Golberg, A.; Alkan, N. Extract from the Macroalgae Ulva rigida Induces Table Grapes Resistance to Botrytis cinerea. Foods 2022, 11, 723. https://doi.org/ $10.3390 /$ foods 11050723

Academic Editor: Jinhe Bai

Received: 19 January 2022

Accepted: 25 February 2022

Published: 28 February 2022

Publisher's Note: MDPI stays neutral with regard to jurisdictional claims in published maps and institutional affiliations.

Copyright: (C) 2022 by the authors. Licensee MDPI, Basel, Switzerland. This article is an open access article distributed under the terms and conditions of the Creative Commons Attribution (CC BY) license (https:// creativecommons.org/licenses/by/ $4.0 /)$.

\begin{abstract}
Fungal pathogens are a central cause of the high wastage rates of harvested fruit and vegetables. Seaweeds from the genus Ulva are fast-growing edible green macroalgae whose species can be found on the shore of every continent, and therefore present a resource that can be utilized on a global scale. In this study, we found that the application of ulvan extract, a sulfated polysaccharide extracted from Ulva rigida (1000 mg/L), elicited table grapes defense and reduced the incidence and decay area of Botrytis cinerea by $43 \%$ and $41 \%$, respectively. In addition, compared to the control group at two days post-treatment, ulvan extract elicited a variety of defense-related biomarkers such as a $43 \%$ increase in the activity of reactive oxygen species, 4 -fold increase in the activity of catalase, 2 -fold increase in the activity of superoxide dismutase and 1.4-fold increase in the activity of chitinase. No increase was observed in phenylalanine ammonia-lyase activity, and the treatment did not affect fruit quality parameters such as the $\mathrm{pH}$ levels, sugar levels, and titratable acidity of grapes. These results illustrate the potential of ulvan extract to naturally induce the plant defense response and to reduce postharvest decay.
\end{abstract}

Keywords: green seaweed; Ulva rigida; ulvan; sulfated polysaccharides; Botrytis cinerea; gray mold; postharvest; induced resistance

\section{Introduction}

According to the FAO, approximately one-third (over 1.3 billion tons) of the total yearly amount of food grown and produced for human consumption worldwide goes to waste. Total global losses for fruit and vegetables range between 43 and 65\%. Besides wasteful practices, which may lead to unnecessary losses of edible fruit and vegetables, a major cause of wastage can be attributed to microbial decay [1]. These postharvest rots are primarily caused by pathogenic fungi. The most effective mean to control pathogenic fungi is using synthetic fungicides on pre- and postharvest fruit and vegetables [2].

Global losses to plant pathogens such as fungi account for $13 \%$ of all global crop losses, with much of the crop and financial cost owing to the fungus Botrytis cinerea, which is known as one of the most detrimental postharvest fungi. B. cinerea infects over 200 host species belonging to more than 170 agricultural plant families, which result in economic losses with estimations up to USD 100 billion/annum worldwide [1-3]. Heavy use of fungicides has led $B$. cinerea to become resistant to many common fungicides [2,3]. Furthermore, due to fungicide toxicity, public concern pushes to restrict fungicides for postharvest use. In response to the detrimental impact of pesticides, new intervention methods of postharvest diseases are underway, such as the utilization of pathogen-antagonistic organisms, use of natural extracts with antifungal activity, development of genetically resistant plants, 
induction of defense response, inhibition of ripening, and more [4-6]. Many of these new postharvest techniques rely on the induction of the innate defense responses found in plants [7]. Plants evolved complex chemical and structural defense mechanisms aimed to perceive, protect, and resist attacks against microorganisms. Upon stimulation, the harvested plant initiates various antifungal chemical and biological defenses [7].

The edible green seaweed of the genus Ulva belongs to the family of green macroalgae (Ulvaceae) and is one of the most common shallow-water seaweed found around the world. Ulva species have been shown to contain several direct antifungal compounds, such as proteins, fatty acids and aromatic compounds, many of which were suggested to have direct antifungal activities [8-10]. "Ulvan" is the main water-soluble, sulfur-containing polysaccharide present in Ulva rigida [11]. Ulvan extract has shown to be efficient against necrotrophic pathogens because it activates plants' jasmonic acid signaling pathway [12] In particular, ulvan extract was shown to induce a large set of defense genes upon treatment of Medicago truncatula leaves and to protect the plant against infection by the pathogenic fungus Colletotrichum trifolii [13]. Additionally, ulvan was shown to protect various plants from three different powdery mildew pathogens [14]. Ulvan has also been shown to elicit defense responses in harvested apple fruit against the phytopathogens Penicillium expansum and Botrytis cinerea [15].

Whilst ulvan has been previously shown to be an effective plant-elicitor as a foliar spray on growing plants, there are only a few studies on ulvan's efficacy in eliciting a defense response during postharvest. Therefore, this study aimed to test the possible postharvest ability of Ulva rigida extracts to control gray mold. First, we screened various Ulva rigida-based extracts against $B$. cinerea conidia germination and hyphal growth to characterize direct hindering effects. Second, we examined the extract's ability to elicit the harvested fruit defense response using the model of harvested table grapes interaction with $B$. cinerea. We found that the crude extractions of ethanol or acetone of Ulva rigida had no direct antifungal effects against the fungus $B$. cinerea in vitro. However, the acidic thermochemical hydrolysis extract (ulvan extract) did show a reduction in the gray mold incidence in vivo. The results of this study suggest that ulvan extract can elicit a defense response in postharvest grapes against the common gray mold and could potentially be used as a future approach to extend the shelf life of table grapes.

\section{Materials and Methods}

\subsection{Preparation of Algal Extracts}

\subsubsection{On-Shore Biomass Cultivation and Processing of Ulva rigida}

Green leafy macroalgae Ulva rigida were cultivated [16], utilizing a closed macroalgae photobioreactor system with the following conditions: the growth media was natural Mediterranean seawater with a salinity range of $37-40$ permille under natural irradiance. Artificial seawater at 37 permille salinity was periodically supplemented by dissolving dried Red Sea salt (Red Sea Fish Inc., Red Sea, Israel) in distilled deionized water with the addition of ammonium nitrate $\left(\mathrm{NH}_{4} \mathrm{NO}_{3}\right.$, Haifa Chemicals Ltd., Haifa, Israel) and phosphoric acid $\left(\mathrm{H}_{3} \mathrm{PO}_{4}\right.$, Haifa Chemicals Ltd., Haifa, Israel) to maintain $6.4 \mathrm{~g} \cdot \mathrm{m}^{-3}$ of nitrogen and $0.97 \mathrm{~g} \cdot \mathrm{m}^{-3}$ of phosphorus. $\mathrm{CO}_{2}$ and $\mathrm{O}_{2}$ were added as bubbled atmospheric air [16].

Fresh wet biomass was harvested and centrifuged in a nylon mesh bag at $4480 \mathrm{~g}$ (Spin Dryer CE-88, Zhenjiang, China) for $1 \mathrm{~min}$ to rid biomass of surface water. Harvested fresh biomass was blended with deionized water (Ninja-BL480, Needham, MA, USA) until $0.5-1 \mathrm{~mm}$ pieces were attained. All blended algae were pooled together in $25 \mathrm{~L}$ of deionized water (heated to $40^{\circ} \mathrm{C}$ for $30 \mathrm{~min}$ ). Ulva rigida biomass was filtered through a fine nylon mesh bag, washed, dried at $40^{\circ} \mathrm{C}$ in an oven, and ground to a fine powder using a coffee grinder (47671, Morphy Richards, Yorkshire, England). The powdered biomass was divided into three groups for ethanolic, acetonic, and aqueous extractions. 


\subsubsection{Thermochemical Extraction}

Extraction procedure performed as described previously with slight modifications [11]. Powdered biomass was funneled into $1 \mathrm{~L}$ borosilicate bottles and filled with $90{ }^{\circ} \mathrm{C}$ deionized water until $3 \% w / v$ was attained. Next, the $\mathrm{pH}$ was adjusted to 2.0 using hydrochloric acid, and the bottles were placed in a water bath at $90{ }^{\circ} \mathrm{C}$ and shook in a reciprocating fashion at $2.5 \mathrm{~Hz}$ for $3 \mathrm{~h}$. The bottles were left to cool to room temperature and filtered through fine nylon mesh bags. The filtrate was collected and centrifuged at $2970 \mathrm{~g}$ for $30 \mathrm{~min}$ (TGL-18 refrigerated centrifuge, Changsha Yingtai Instrument Co., Ltd., Changsha City, China). The collected supernatant was divided amongst $50 \mathrm{~mL}$ tubes and mixed with $70 \%$ ethanol cooled to $-80^{\circ} \mathrm{C}$ in a 1:4 (supernatant to ethanol) ratio and shaken for $15 \mathrm{~s}$ in a vortex. The test tubes were centrifuged at $16,050 \mathrm{~g}$ for $30 \mathrm{~min}$ at $4{ }^{\circ} \mathrm{C}$. The supernatant salinity was measured with a conductometer, discarded, and the precipitate ("ulvan extract") was again mixed with $70 \%$ ethanol, vortexed, and centrifuged. This process was repeated until the supernatant above the ulvan extract precipitate indicated a conductivity of $<10 \mu \mathrm{S} / \mathrm{cm}$. The ulvan extract precipitate was placed in a $40{ }^{\circ} \mathrm{C}$ oven until it was completely dried. Then, the dried pellet was crushed using a mortar and pestle and liquid nitrogen, and consequently freeze-dried in a lyophilizer (Freezedryer Ilshin Biobase Co., Ltd., Ede, The Netherlands).

The ulvan extraction yield was calculated in the following manner:

$$
\text { Yield } \%=\frac{\text { Dry weight of ethanol precipitate }}{\text { Dry weight of Ulva rigida }} \times 100
$$

\subsubsection{Organic Solvents Extraction}

The organic solvents extraction was carried out with slight modification [10]. Powdered biomass of $100 \mathrm{~g}$ was divided into 2 groups and funneled into 2 separate 1 L borosilicate bottles. One bottle was filled with $500 \mathrm{~mL}$ of absolute ethanol (EtOH) and the other bottle with $500 \mathrm{~mL}$ of acetone (Ethanol, Acetone, Sigma-Aldrich, Jerusalem, Israel). Each bottle was covered with aluminum foil and placed on magnetic stirring for $120 \mathrm{~h}$ at room temperature.

The contents of the bottles were separately filtered through a fine nylon mesh bag, and each filtrate was placed separately in a rotary evaporator under vacuum and concentrated to $100 \mathrm{~mL}$, then further concentrated at $40{ }^{\circ} \mathrm{C}$ until a dark precipitate formed $(\approx 50 \mathrm{~mL})$. The extracts from the acetone and the ethanol extractions were assumed to be in maximum solubility and were used for all experiments, henceforth referred to as "Ulva-Acetone" and "Ulva-EtOH".

\subsubsection{Characterization and Chemical Composition Analysis}

Fourier Transform Infrared (FT-IR) spectra of vacuum-dried ulvan extract biomass were measured in the spectral range of $400-4000 \mathrm{~cm}^{-1}$ (at $4 \mathrm{~cm}^{-1}$ resolution) using an FT-IR machine (Bruker Tensor 27 FT-IR, Bruker, Ettlingen, Germany). The identification of the thermochemical hydrolysis extract from Ulva sp. was compared to the extract's features and values of previous studies, and the percentage of similarity was calculated.

Elemental analysis (CHNS) was undertaken using CHNS Analyzer (Flash2000 CHNS/O Analyzer, Thermo Fischer Scientific, Waltham, MA, USA) at Technion Chemistry Service Unit (Israel Institute of Technology, Haifa, Israel). The elemental analysis was compared to previously published data (Table S1).

\subsection{In Vitro Effects of Ulva rigida Extracts on B. cinerea Fungus}

\subsubsection{In Vitro Effect of Extracts on Conidia Germination}

Botrytis cinerea was isolated from an infected red pepper. The mycelium was routinely grown on potato dextrose agar (PDA; Difco, NJ, USA) at $23^{\circ} \mathrm{C}$. B. cinerea conidia were isolated from a sporulating 14-day old plate by suspension in sterile distilled water and filtering through sterile cheesecloth. The conidia were diluted with double deionized water 
to a concentration of $10^{5}$ conidia $\mathrm{mL}^{-1}$. Conidial concentration in the suspension was microscopically determined using a hemocytometer.

Germination tests with slight modification [17] were performed on microscopic glass slides. Solutions of various additives were made by mixing $0.2 \%$ Sabouraud maltose broth (SMB; 10 gr Peptone (Difco), 40 g Maltose (Caisson labs, Smithfield, UT, USA) per $1 \mathrm{~L}$ ) with either algal extracts or water. The solutions prepared were: $0.5 \% v / v$ Ulva-EtOH extract, $0.5 \% v / v$ Ulva-Acetone extract, $0.5 \% v / v$ EtOH, $0.5 \% v / v$ acetone, $0.05 \% v / v$ ulvan extract, $0.1 \% v / v$ ulvan extract, $0.5 \% v / v$ ulvan extract, $0.2 \% v / v$ SMB. A $10 \mu \mathrm{L}$ drop of each solution was added to a $10 \mu \mathrm{L}$ conidial suspension of $10^{5}$ Conidia $\mathrm{mL}^{-1}$. The slides were incubated in a humid chamber at room temperature for $24 \mathrm{~h}$. Each slide was photographed under a microscope (Leica DM500, ICC50 HD camera, Heerbrugg, Switzerland) 4 times at different locations at $10 \times$ magnification, and four photos of different areas of the slide at $40 \times$ magnification. The lengths of conidia germ tubes and germination percentages were measured across all photographs using ImageJ.

\subsubsection{In Vitro Effect on Mycelium Grown on Agar Plate}

PDA Petri dishes were made with descending concentrations of extracts (for acetonic and ethanolic extracts: $0.5 \%, 0.25 \%$, and $0.125 \% v / v$ ). Control plates were made having the same descending concentrations of ethanol, acetone, or PDA only. All plates were made in triplicate. The PDA plate was inoculated with $1 \mathrm{~cm}^{2}$ piece of $B$. cinerea mycelium from a 10-day-old plate. The plates were incubated at room temperature for seven days. The mycelium diameter was measured each day.

\subsubsection{In Vitro Effect on Fungal Growth Kinetics}

Fungal growth kinetics with slight modification [17] was measured using a 96-well plate (Bar-Naor Ltd., Petah Tikva, Israel). Algal ethanolic, acetonic, and ulvan extracts of $1 \%$ to $0.125 \%$ were diluted in $1 \%$ SMB. Then, $200 \mu \mathrm{L}$ from each dilution was pipetted into a 96-well plate in triplicate. Conidial suspension of $10 \mu \mathrm{L}\left(10^{5} \mathrm{Conidia}_{\mathrm{mL}}^{-1}\right)$ was added to each well and mixed thoroughly. "Blanks" were filled with algal dilutions without conidial suspension. The plate was incubated at room temperature, and optical density measurements at $600 \mathrm{~nm}\left(\mathrm{OD}_{600}\right)$ were taken every hour for $60 \mathrm{~h}$ using a Synergy LX plate reader (BioTek, Winooski, VT, USA). The absorbance of three wells of repeats was averaged together and was background-corrected by subtracting the average absorbance of media alone at time zero [17].

\subsection{Measuring Fruit Response to Ulva rigida Extracts}

\subsubsection{In Vivo Test on Grapes Inoculated with B. cinerea}

Pathogenicity assays with slight modification were based on [18]. Similar weight, size, and with no visible surface blemishes grapes (Vitis vinifera $\mathrm{cv}$. 'Scarlotta' Tali Grapes ${ }^{\odot}$, Moshav Lachish, Israel, $31^{\circ} 33^{\prime} 42^{\prime \prime} \mathrm{N} 34^{\circ} 50^{\prime} 34^{\prime \prime}$ E) were harvested in October. In total, 150 grapes were cut at the pedicel, $1 \mathrm{~cm}$ above the grape flesh. The grapes were rinsed with water and dried, followed by a spray of $70 \%$ ethanol, and dried. The grapes were divided into two groups, each group was dipped for $1 \mathrm{~min}$ in a solution of either $1000 \mathrm{mg} / \mathrm{L}$ ulvan extract or DDW, left to dry, and kept at room temperature. Two days post-treatment (DPT), 40 grapes from each treatment group were punctured with a sterilized needle at $1 \mathrm{~mm}$ depth following inoculation with $10 \mu \mathrm{L}$ conidial suspension $\left(10^{5}\right.$ Conidia $\left.\mathrm{mL}^{-1}\right)$ and incubated at room temperature for seven days in humid conditions. The decay diameter was measured every day, and the decay incidence (percentage of infected grapes) was calculated. The decayed area was calculated by assuming each grape is a perfect ellipse with an area of $235 \mathrm{~mm}^{2}$ (major axis: $\approx 20 \mathrm{~mm}$, minor axis: $\approx 15 \mathrm{~mm}$ ) and dividing the 
area of fungal growth $\left(\mathrm{mm}^{2}\right)$ by the ellipse area and taking the total daily average for each group of treated grapes, where: $n=$ number of samples.

$$
\% \text { decay area }=\frac{1}{n} \sum_{i=1}^{n} \frac{\text { fungal growth }}{235} \times 100
$$

\subsubsection{Evaluation of Fruit Quality Parameters}

Physiological parameters of the grapes-total soluble sugars (TSS), $\mathrm{pH}$, and titratable acidity (percentage malic acid equivalence)—were tested on the first day (before treatment) and on 2 or 4 DPT, and with slight modification based on [19]. For testing of TSS, 4 un-inoculated grapes from each treatment (ulvan extract or DDW (control)) were randomly selected, placed inside sterilized gauze and collectively crushed, and the filtered juice was collected. Filtered juice of $1 \mathrm{~mL}$ from each tested group was placed in a Palette digital-refractometer PR-1 (Model DBX-55, Atago, Japan), and each measurement was repeated in triplicate.

For acidity determination, 7 un-inoculated grapes from every treatment (ulvan extract or DDW (control)) were randomly selected for testing in the following manner: $1 \mathrm{~mL}$ of pulp juice was dissolved in $40 \mathrm{~mL}$ double-distilled water and determined as malic acid equivalent mass using an automatic titrator (Model 719s, TitrinoMetrohm Ion Analysis Ltd., Herisau, Switzerland).

\subsubsection{Reactive Oxygen Species Levels}

Method for determining reactive oxygen species (ROS) was based on Galsurker et al. (2020) with slight modification [19]. Five ulvan-treated grapes and 5 DDW-treated grapes were tested on 2 and 4 DPT. The grapes were submerged in $10 \mu \mathrm{M}$ DCF $\left(2^{\prime}, 7^{\prime}-\right.$ Dichlorofluorescein, Sigma-Aldrich, St. Louis, MO, USA) in phosphate-buffered saline (PBS) and placed on an orbital shaker at $1.6 \mathrm{~Hz}$ for $15 \mathrm{~min}$ in the dark. Followed by destaining with PBS solution on the orbital shaker for $1 \mathrm{~min}$, and the washing repeated twice.

The fluorescence was measured at $488 \mathrm{~nm}$ excitation and $510 \mathrm{~nm}$ emission using in- vivo Imaging System (IVIS ${ }^{\circledR}$, PerkinElmer, Inc., Waltham, MA, USA) Results were calculated using IVIS ${ }^{\circledR}$ Lumina II imaging system software (PerkinElmer, Inc., Waltham, MA, USA) and expressed in units of radiance $\left[\mathrm{p} / \mathrm{s} / \mathrm{cm}^{2} / \mathrm{sr}\right]$.

\subsubsection{Free Radical Scavenging Activity}

DPPH (2,2-Diphenyl-1-picrylhydrazyl; D9132, Sigma-Aldrich, Jerusalem, Israel) was used to represent the overall antioxidant of the sample, according to the method described by Cheung et al. (2003), with slight modifications [20]. Grape peel samples were collected at 2 or 4 DPT. All samples were crushed to a powder using a mortar and pestle and liquid nitrogen. For each sample, $500 \mathrm{mg}$ of powder was mixed with $3 \mathrm{~mL}$ of $70 \%$ methanol and shaken on an orbital shaker at $5 \mathrm{~Hz}$ for $3 \mathrm{~h}$, after which samples were centrifuged at $2349 \mathrm{~g}$ for $20 \mathrm{~min}$ at room temperature. The supernatant was evaporated in rotorvap (RE-201D, Henan Province, China) at $25^{\circ} \mathrm{C}$ for $6 \mathrm{~h}$ until $1 \mathrm{~mL}$ of the solution was left. The samples were stored at $-20{ }^{\circ} \mathrm{C}$ until use.

A working stock solution of $0.012 \mathrm{~g}$ of DPPH was made by diluting with $50 \%$ methanol until an absorbance of $1 \pm 0.02$ at $517 \mathrm{~nm}$ was obtained. DPPH $(990 \mathrm{~mL})$ was mixed with $10 \mu \mathrm{L}$ sample solutions, and the absorbance was taken at $517 \mathrm{~nm}$ using a spectrometer (Synergy LX Multi-Mode Reader, Biotek Instruments, Winooski, VT, USA). Control solutions were prepared as above with the addition of $10 \mu \mathrm{L}$ water instead of sample solution. The amount of antioxidants was calculated using a calibration curve which was made by measuring the scavenging activity of ascorbic acid at various concentrations (0.01-0.5 g/L) [21] Each treatment and concentration were tested in triplicates. 


\subsubsection{Enzymatic Activity and Protein Assays}

For all enzymatic assays, frozen grape peel samples were crushed to a powder using a mortar and pestle and liquid nitrogen. The protein content of enzyme extracts was calibrated by a dye-binding method of [22] with bovine serum albumin (BSA) as a standard. For each treatment and concentration, triplicates were made and tested before treatment and 2 and 4 DPT.

Phenylalanine ammonia-lyase (PAL) activity was determined according to Assis et al. (2001), with slight modification [23]. In total, $500 \mathrm{mg}$ of frozen powder was homogenized with $2 \mathrm{~mL}$ of borate buffer $(100 \mathrm{mM}, \mathrm{pH} 8.8)$ containing $5 \mathrm{mM} \beta$-mercaptoethanol and $2 \mathrm{mM}$ ethylenediaminetetraacetic acid (EDTA), centrifuged for $30 \mathrm{~min}$ at $2349 \mathrm{~g}$ at $4{ }^{\circ} \mathrm{C}$, and the supernatant collected. Then, $75 \mu \mathrm{L}$ of supernatant was incubated with $150 \mu \mathrm{L}$ of borate buffer ( $50 \mathrm{mM}, \mathrm{pH} 8.8$ ) containing $20 \mathrm{mM}$ L-phenylalanine for $60 \mathrm{~min}$ at $37^{\circ} \mathrm{C}$. After incubation time, the reaction was stopped by adding $75 \mu \mathrm{L}$ of $1 \mathrm{M}$ hydrochloric acid $(\mathrm{HCl})$, and the production of cinnamate was measured at $290 \mathrm{~nm}$. The specific enzyme activity was expressed as nmol cinnamic acid $\mathrm{h}^{-1} \mathrm{mg}$ of protein $^{-1}$.

Chitinase activity was estimated according to [24]. A total of $500 \mathrm{mg}$ of frozen powder was homogenized by $2 \mathrm{~mL} 50 \mathrm{mM}$ sodium acetate buffer ( $\mathrm{pH}$ 5.0), centrifuged for $30 \mathrm{~min}$ at $2349 \mathrm{~g}$ at $4{ }^{\circ} \mathrm{C}$, and the supernatant collected. Then, $600 \mu \mathrm{L}$ of supernatant was mixed with $125 \mu \mathrm{L}$ of $2 \%(w / v)$ dye-labeled chitin azure in $50 \mathrm{mM}$ sodium acetate buffer (pH 5.0) and incubated for $120 \mathrm{~min}$ at $40{ }^{\circ} \mathrm{C}$. After incubation, the reaction was terminated by adding $25 \mu \mathrm{L}$ of $1 \mathrm{M} \mathrm{HCl}$, and the supernatant was measured at $550 \mathrm{~nm}$. One unit was defined as the amount of enzyme needed to catalyze the formation of $1 \mathrm{nmol}$ product $\mathrm{h}^{-1} \mathrm{mg}$ of protein $^{-1}$.

Catalase (CAT) activity was estimated by the method of Beers and Sizer (1952) with a slight modification [25]. First, $500 \mathrm{mg}$ of frozen powder was homogenized with $2 \mathrm{~mL}$ of sodium phosphate buffer ( $100 \mathrm{mM}, \mathrm{pH} 7)$, centrifuged for $30 \mathrm{~min}$ at $2349 \mathrm{~g}$ at $4{ }^{\circ} \mathrm{C}$ and the supernatant collected. The reaction mixture contained $50 \mu \mathrm{L}$ of supernatant, $150 \mu \mathrm{L}$ of sodium phosphate buffer (100 mM, pH 7.0), and $50 \mu \mathrm{L}$ of $\mathrm{H}_{2} \mathrm{O}_{2}(100 \mathrm{mM})$. The $\mathrm{H}_{2} \mathrm{O}_{2}$ decomposition was measured at $240 \mathrm{~nm}$ absorbance. The enzyme activity was expressed as units per mg protein (one unit = catalase converts $1 \mu \mathrm{mol}$ of $\mathrm{H}_{2} \mathrm{O}_{2}$ per min).

Super-oxide dismutase (SOD) activity was assayed according to Giannopolitis and Ries (1977) with slight modification [26]. In total, $100 \mathrm{mg}$ of frozen powder was homogenized with $200 \mu \mathrm{L}$ sodium phosphate buffer $(100 \mathrm{mM}, \mathrm{pH} 7.8)$, centrifuged for $30 \mathrm{~min}$ at $2349 \mathrm{~g}$ at $4{ }^{\circ} \mathrm{C}$, and the supernatant was collected. A reaction solution containing sodium phosphate buffer (100 mM, pH 7.8), methionine (13 mM), nitroblue tetrazolium (NTB; $75 \mu \mathrm{M})$, EDTA $(10 \mu \mathrm{M})$, and riboflavin $(2 \mu \mathrm{M})$, was mixed in a 1:1 ratio with $100 \mu \mathrm{L}$ of collected supernatant. The mixture was illuminated through a fluorescent lamp $\left(60 \mu \mathrm{mol} \mathrm{m}^{-2} \mathrm{~s}^{-1}\right)$ for $10 \mathrm{~min}$, and the absorbance was read at $560 \mathrm{~nm}$. For the blank, identical solutions were kept under the dark. The enzyme activity was expressed as unit $\mathrm{mg}^{-1}$ of protein. One unit was defined as the amount of enzyme that caused 50\% inhibition of NBT.

The final enzymatic activity of CAT, PAL, and chitinase was calculated in the following manner:

$$
\text { CAT, PAL, Chitinase activity }=\frac{1}{n} \sum_{\mathrm{i}=1}^{n} \frac{\mathrm{A}_{\mathrm{i}, 0}-\mathrm{A}_{\mathrm{i}, 1}}{\mathrm{~A}_{\mathrm{i}, 0}} \times 100
$$

and the SOD activity was calculated in the following manner:

$$
\text { SOD activity }=\frac{1}{n} \sum_{\mathrm{i}=1}^{n} \frac{\left(\frac{\mathrm{A}_{\mathrm{i}, 0}-\mathrm{A}_{\mathrm{i}, 1}}{\mathrm{~A}_{\mathrm{i}, 0}}\right)}{50 \%} \times \frac{\text { reaction volume }}{\text { sample volume }} \times \text { dilution factor }
$$

where: $n=$ number of samples; $\mathrm{A}_{\mathrm{i}, 0}=$ control absorbance; $\mathrm{A}_{\mathrm{i}, 1}=$ sample absorbance. 


\subsection{Statistical Analysis}

The data presented are averages and standard errors. A $t$-test was performed to compare two treatments. One-way or two-way analysis of variance (ANOVA) was used when applicable and post-hoc tests were conducted using Tukey's HSD pairwise comparison and the Dunn-Šidák correction, using JMP Pro 15 (SAS Institute, Cary, NC, USA).

\section{Results}

\subsection{In Vitro Effects of Ulva rigida Extracts on B. cinerea Growth}

The effect of the Ulva rigida extracts on B. cinerea germination and growth was evaluated. Conidia of $B$. cinerea was germinated in $0.2 \%$ SMB medium with or without the addition of Ulva rigida extracts. The addition of the various ulvan extract concentrations had shown no effect on B. cinerea germination, resulting in $100 \%$ germination incidence after $24 \mathrm{~h}$ both in control and after the addition of the various extracts (Figure 1). Moreover, all germinated conidia in Ulva extracts had longer and more branched germ tubes compared to the control. The effect of the ulvan extract on the germination tube elongation was in a dose-dependent manner indicating its role as a carbon source for fungal growth (Figure 1). For all organic solutions containing algal extracts, fungal growth was always larger than their control counterparts. As the concentration of the acetone or ethanol decreases in the control plates, a more pronounced growth pattern can be seen due to the impeding effect of these organic solutions (Figure 1). At hindering concentrations of organic solutions, once algal material was present, increased fungal growth was evident (Figure 1).

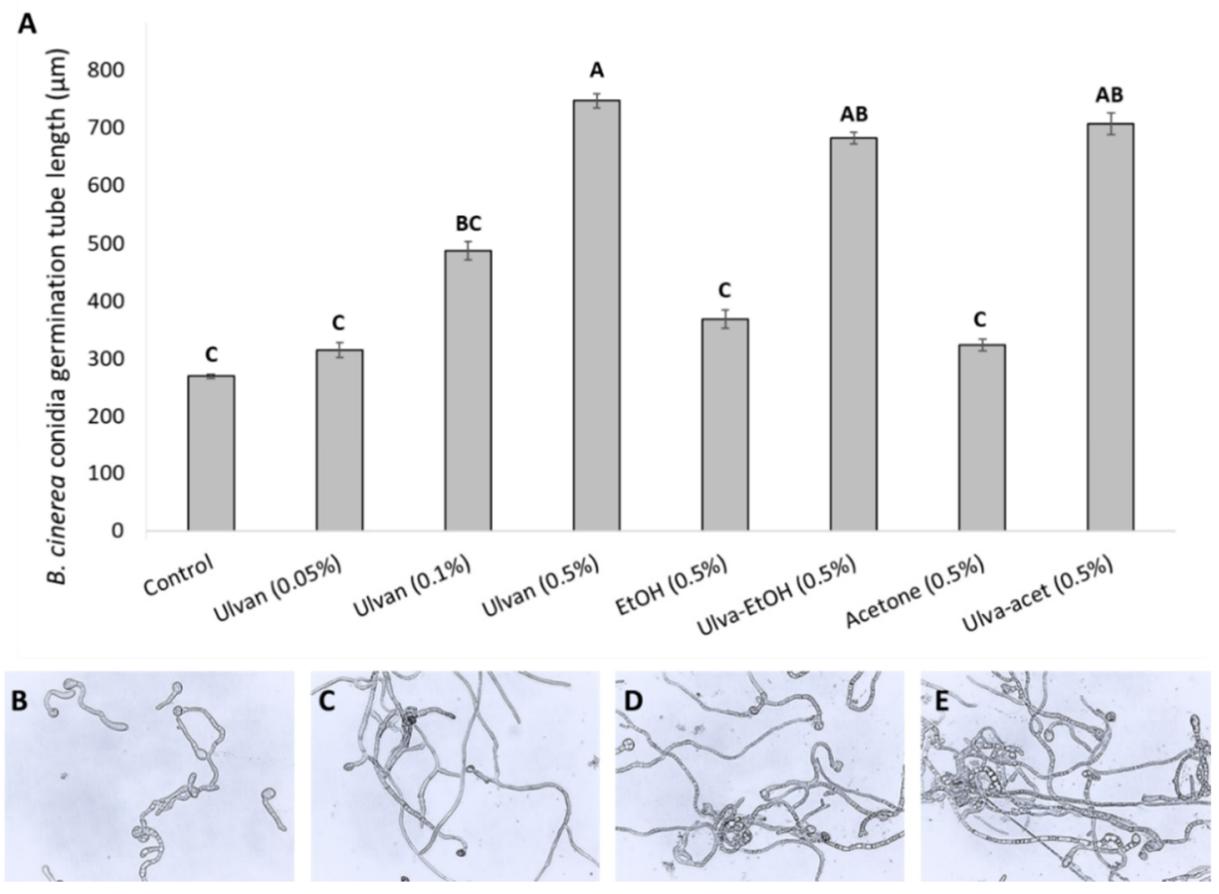

Figure 1. Ulva extracts promote in vitro growth of B. cinerea in Sabouraud maltose broth medium. Conidia of $B$. cinerea were germinated on glass in the presence of SMB medium and ulvan or different acetonic (acet) or ethanolic $(\mathrm{EtOH})$ algal extracts in various concentrations in humid conditions at $23{ }^{\circ} \mathrm{C}$ for $24 \mathrm{~h}$. (A) Length of $B$. cinerea conidia germination tube. Average and SE are presented. Different letters indicate a statistical difference $(p \leq 0.05)$. (B-E) Representative pictures of $B$. cinerea conidia germination after $24 \mathrm{~h}$. (B) Control (0.2\% SMB), (C) $500 \mathrm{mg} / \mathrm{L}$ ulvan extract, (D) $500 \mathrm{mg} / \mathrm{L}$ Ulva-EtOH, (E) $500 \mathrm{mg} / \mathrm{L}$ Ulva-Acetone.

Next, the effect of the crude ethanolic and acetonic extract on B. cinerea growth and mycelial development was examined. $B$. cinerea conidia were grown in SMB medium in the presence of acetonic or ethanolic extracts. In both the ethanolic and acetonic extracts, $B$. 
cinerea growth was higher than the growth in the SMB medium with the same percentage of organic solvent (Figure S1A,B). Similar results were observed in mycelial growth on agar plate supplemented with the algal extracts (Figure S1C). This suggests that the fungus probably found a nutritional value within the algal extracts leading to more pronounced germination, hyphal branching, and overall greater mycelial development (Figure 1 and Figure S1).

\subsection{In Vivo Effects of Ulva rigida Extract on B. cinerea Growth}

Preliminary work has shown that neither the ethanolic nor the acetonic extracts had any significant effects in culling disease severity and incidence when compared to the control group (Figure S2). Therefore, we aimed to examine the capability of ulvan extract to induce defense response in table grapes. "Scarlotta" table grapes were disinfected and treated with $1000 \mathrm{mg} / \mathrm{L}$ ulvan extract. At 2 DPT, the grapes were punctured with a sterilized needle at $1 \mathrm{~mm}$ depth, followed by inoculation with $10 \mu \mathrm{L}$ conidial suspension $\left(10^{5}\right.$ Conidia $\left.\mathrm{mL}^{-1}\right)$ and monitored at room temperature for seven days in humid conditions. The application of $1000 \mathrm{mg} / \mathrm{L}$ ulvan extract on "Scarlotta" winter grapes showed a decrease in gray-mold decay in terms of decay area and decay incidence. Grapes that were treated with ulvan extract showed a $41 \%$ decrease in decay area and a $43 \%$ reduction in incidence on the fourth day post-inoculation (DPI) compared to the control group. At $7 \mathrm{DPI}$, the group treated with ulvan extract showed an $8.8 \%$ reduction in incidence and a $48.4 \%$ reduction in mean decay area when compared to the water-treated control group (Figure 2), which may indicate that ulvan treatment induces defense response mechanisms in table grapes.
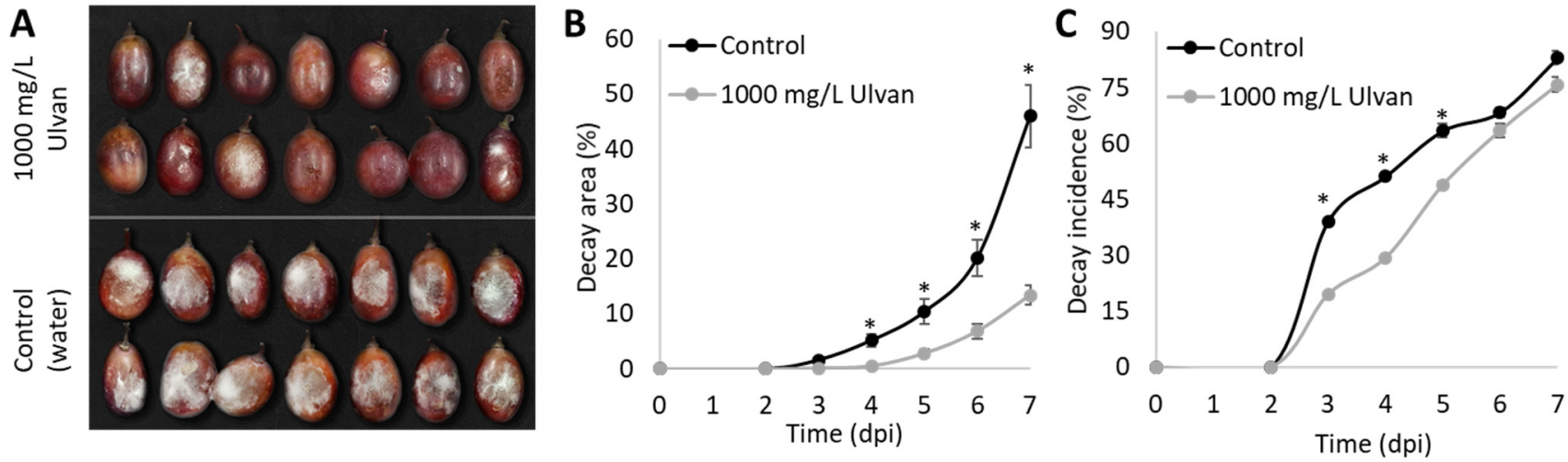

Figure 2. Ulva rigida crude aqueous extract (ulvan extract) decreases gray mold on grapes. "Scarlotta" grapes were treated with either $1000 \mathrm{mg} / \mathrm{L}$ ulvan or double deionized water (control), followed by inoculation with B. cinerea, two days post-treatment (DPT). (A) Representative picture of gray-mold decay caused by B. cinerea inoculation on grapes treated with $1000 \mathrm{mg} / \mathrm{L}$ ulvan extract or water (control), four days post-inoculation (DPI). (B) Decay area (\% of fruit side). (C) Decay incidence (\% of inoculated fruit). Asterisks indicate statistical difference between treatments at each time point $(p \leq 0.05)$.

\subsection{Induction of Fruit Defense Response}

To understand which defense response pathways the ulvan treatment might affect, major defense pathways and pathogenesis-related enzymes were tested. First, ROS levels were determined. Un-inoculated grapes, which were treated with ulvan extract, showed a statistical increase in ROS levels compared to the water-treated, control group, on 2 DPT and even more on 4 DPT. Grapes treated with ulvan extract had a $43 \%$ increase in ROS compared to the DDW-treated group on day 4 (Figure 3). 

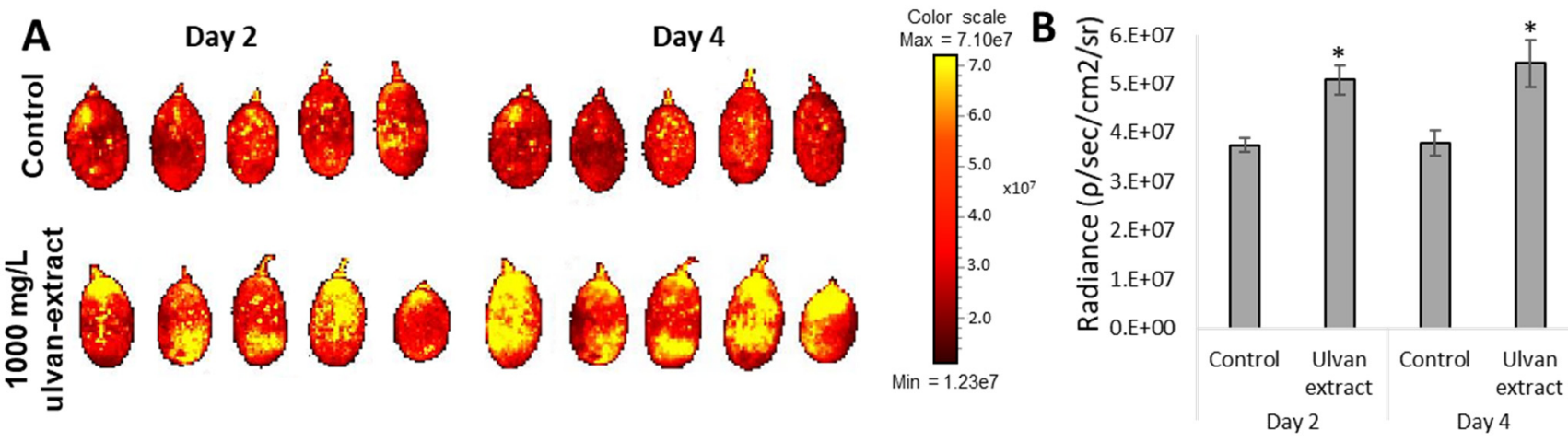

Figure 3. Changes in reactive oxygen species (ROS) levels. "Scarlotta" grapes were treated with $1000 \mathrm{mg} / \mathrm{L}$ ulvan extract or double deionized water (Control). The fruit was dyed with DCF, and the fluorescence (radiance $\left[\mathrm{p} / \mathrm{s} / \mathrm{cm}^{2} / \mathrm{sr}\right]$ ) was detected using an In vivo Imaging System (IVIS ${ }^{\circledR}$ ). (A) Average radiance was quantified on 2 and 4 DPT. Asterisks indicate statistical significance between treatments $(p \leq 0.05)$. (B) Fluorescence was visualized on 2 and 4 DPT.

Next, the effect of ulvan extract treatment was examined on the activity of several defense response-related enzymes. Treatment with ulvan extract increased the activity of grape SOD when compared to the water-treated group. While at 2 DPT the ulvan extract treated grapes displayed a non-significant increase in SOD activity compared to the control group, at 4 DPT the SOD activity was significantly higher by 2 -fold in the ulvan extract treated grapes compared to the control group (Figure 4A). The overall CAT activity in the ulvan extract treated group was higher than in the control group. At $4 \mathrm{DPT}$, the CAT activity was 4 -fold greater than in the control group (Figure 4B). However, the total antioxidant concentration (DPPH) was lower for the ulvan extract treated group compared to the control group (Figure S3).

Ulvan extract did not show an increase in PAL activity when compared to the control. In both treatments (ulvan extract and control), an increase was observed, peaking on 2 DPT, and decreasing by the 4 DPT (Figure 4C). Chitinase activity in grapes treated with ulvan extract revealed a 1.4-fold increase in activity 2 DPT compared to initial levels, while watertreated grapes showed almost no change in the chitinase activity 2 DPT compared to initial levels. By the 4 DPT the levels were reduced back to the initial levels with no differences between the treatments (Figure 4D). While treatment with ulvan extract induced the fruit defense response (Figure 4), it did not affect the fruit ripening (Table S2). Grapes treated with $1000 \mathrm{mg} / \mathrm{L}$ ulvan extract did not lead to any changes in $\mathrm{pH}$ levels, sugar levels (TSS), nor in titratable acidity in comparison to the control, on any day post-treatment (Table S1).

\subsection{Characterization and Chemical Composition of Crude Extract of Ulva rigida Sulfated Polysaccharides (Infrared Spectroscopy and Elemental Analysis)}

Ulva rigida was grown and used for several extractions (ethanol or acetone crude extraction, as well as thermochemical sulfated polysaccharides extraction). The extraction of Ulva rigida crude aqueous extract (ulvan extract; Figures 3-5) was conducted using the thermochemical extraction method, yielding approximately $25.06 \%$ ulvan. To validate the ulvan chemical structure, infrared spectral data obtained from a sample of ulvan extract was analyzed across a range of wavelengths $\left(400-4000 \mathrm{~cm}^{-1}\right)$, using Fourier-transform infrared spectroscopy (FT-IR). The analysis provides a distinctive molecular fingerprint of the sample (Figure 5). The FT-IR analysis revealed characteristic peaks of sulfur-containing polysaccharides, and a full analysis of the spectra is available in Supplementary Table S2. For further characterization, the elemental analysis of carbon, hydrogen, nitrogen, and sulfur was performed using a CHNS Analyzer. The elemental components are presented as weight percentages out of the total dry weight (DW) of the sample (Table 1). Comparison of the elemental analysis results with similar extracts which were presented in previous 
studies found that the percentages of the elements of the current ulvan extract are within typical ranges for such an extract [27-29].
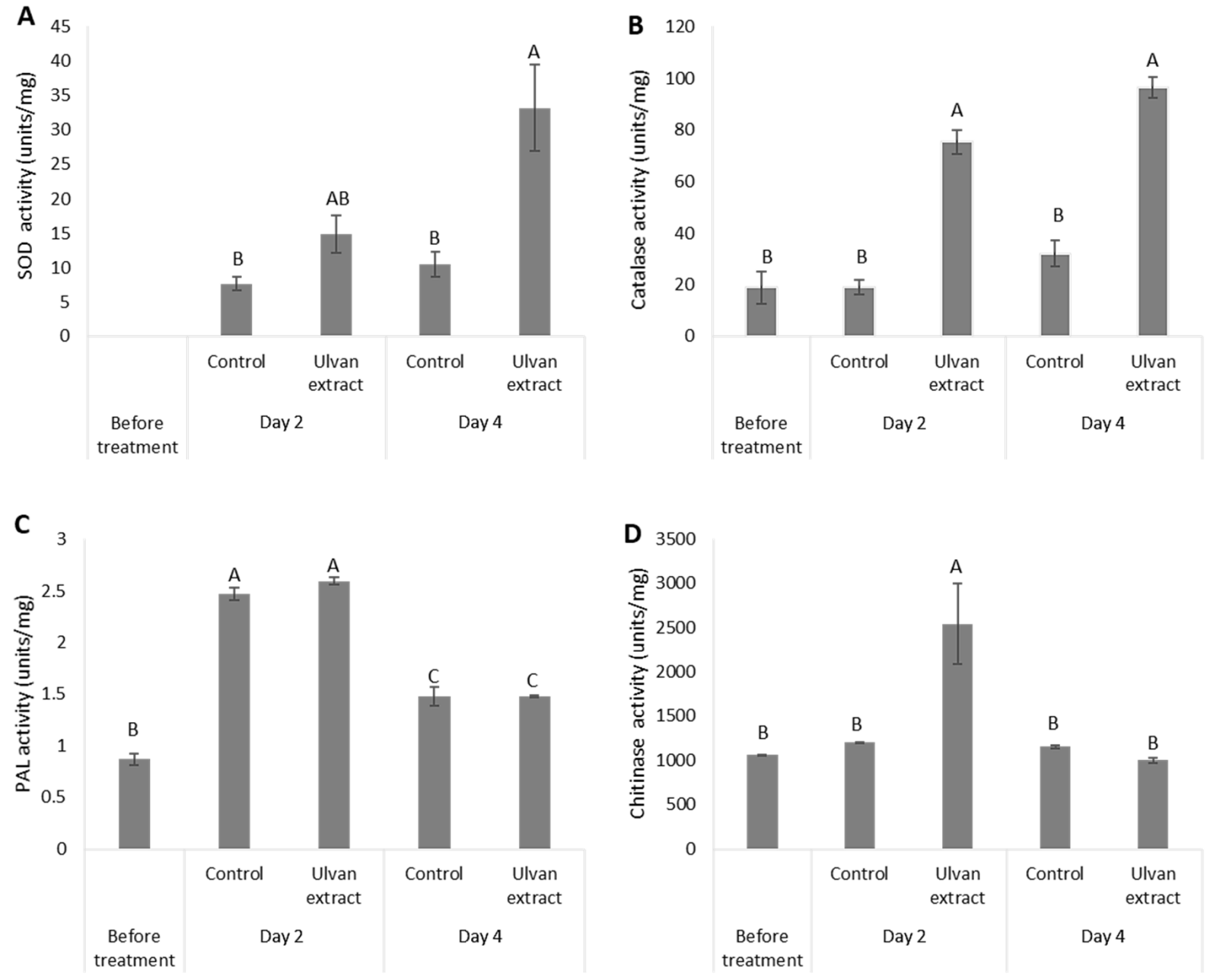

Figure 4. Changes in fruit enzymatic activity of plant-defense biomarkers. Enzymatic activity of (A) superoxide dismutase (SOD), (B) catalase (CAT), (C) phenylalanine ammonia-lyase (PAL), and (D) chitinase in uninoculated "Scarlotta" grapes treated with $1000 \mathrm{mg} / \mathrm{L}$ ulvan extract or water (control) on two- and four-days post-treatment (DPT). Different letters indicate as difference $(p \leq 0.05)$.

Table 1. Thermochemical acidic hydrolysis extract of Ulva rigida (ulvan) elemental composition. Analysis of carbon $(\mathrm{C})$, hydrogen $(\mathrm{H})$, nitrogen $(\mathrm{N})$, and sulfate $(\mathrm{S})$ in the current study compared to the literature.

\begin{tabular}{lcccc}
\hline \multicolumn{1}{c}{ \% of DW } & C & H & N & S \\
\hline Ulvan extract in the current study $\#$ & 22.74 & 4.61 & 0.63 & 7.00 \\
Costa et al., 2012 [27] & 22.80 & 4.30 & 1.00 & 8.40 \\
del Rocío Quezada-Rodríguez and Fajer-Ávila, 2017 [28] & 19.47 & 3.78 & 0.89 & 8.69 \\
Lahaye and Robic, 2007 [29] & 19.35 & 3.88 & 0.98 & 5.62 \\
\hline
\end{tabular}

\# Data display the average of three repeats. 


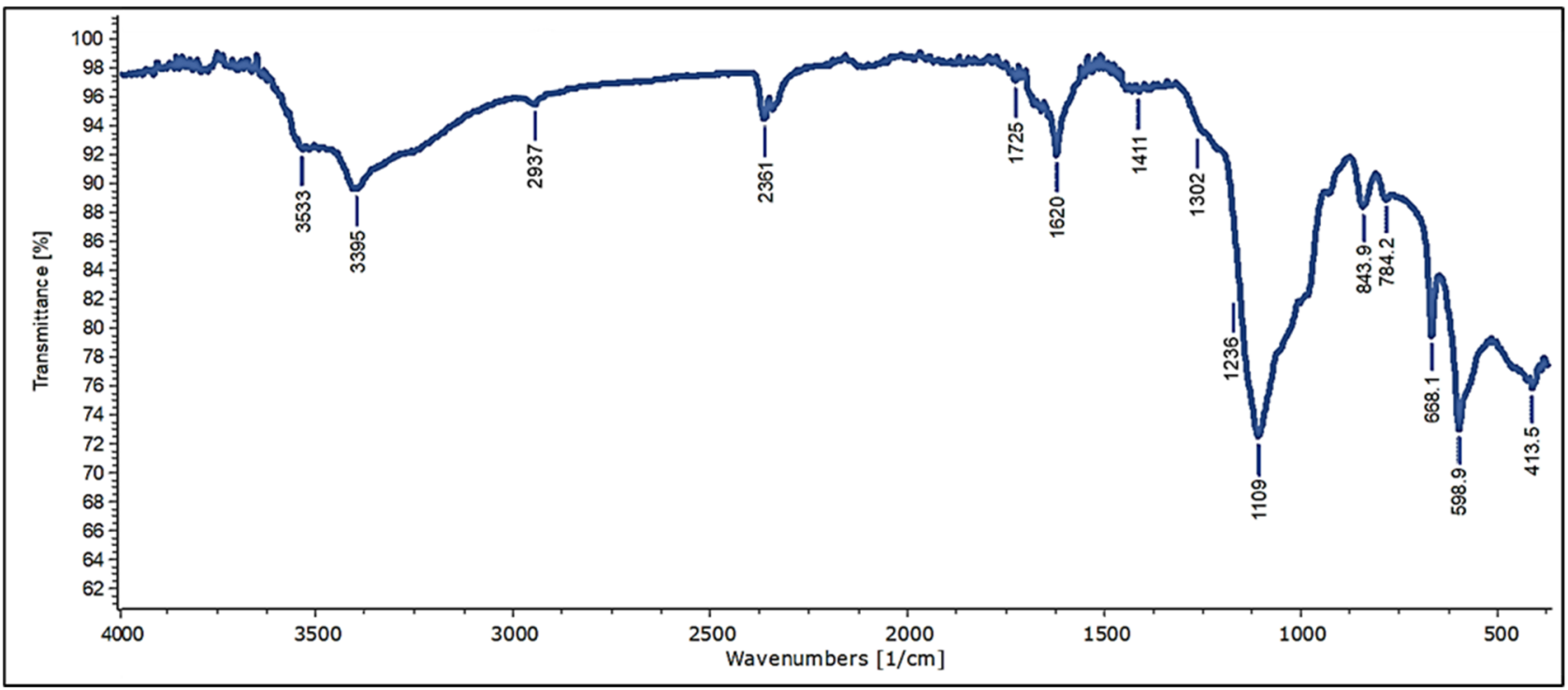

Figure 5. The Fourier-transform infrared spectrum (FT-IR). Protruding peaks correspond to chemical structures found within the sample of ulvan extract, and the numbers correspond to the vibration frequency of the chemical structures. Larger peaks show a greater abundance of these structures within the sample.

\section{Discussion}

Global postharvest losses for fruit and vegetables are estimated at $40 \%$. Major loss is contributed to postharvest diseases, caused mainly by fungal pathogens. Although chemical fungicides are considered the most effective treatment against postharvest diseases, their long-term toxicity to the environment and human health is a major disadvantage and raises the need for new environmentally friendly solutions. Ulvan's structure and antimicrobial functionality have been previously studied on various plant models and pathogens during the plants' growing stage, while research on postharvest produce has been scarce. In general, most research was focused on increasing food production, while a substantially smaller focus was directed towards reducing losses [30]. Therefore, in the current study, we aimed to investigate the possible effect of different Ulva rigida extracts to control the pathogenic fungi $B$. cinerea growth and decay.

Ulva rigida was chosen due to its easy cultivation in various mediums on and offshore, with the advantage of having one of the fastest biomass growth rates amongst all photosynthesizing organisms and a rich source of biochemical functional components. Ulva species are one of the most common seaweeds found around the world, making Ulva a globally available marine resource. In addition, Ulva species were shown to possess a high amount and diversity of carbohydrates [31].

The first step in this study was to examine a possible direct antifungal effect of different Ulva extracts (ethanolic, acetonic, or aqueous extraction) on fungal conidia germination and hyphal growth. In this work, none of the Ulva rigida extracts demonstrated any hindering abilities on B. cinerea conidia germination (Figure 1 and Figure S1). Similar results of no effect on fungal germination were observed in other papers [32,33]. This is likely due to the fungus considering the algal material as a source of nutrition. Even at hindering concentrations of organic solutions, once algal material was present, an increase in fungal growth was evident (Figure 1 and Figure S1 and S2). Methanol extract from Ulva sp. at $1000 \mathrm{mg} / \mathrm{L}$ inhibited Colletotrichum lindemuthianum conidia germination while ulvan extract promoted fungal growth [10]. However, no methanolic control was conducted.

Since our data did not support the direct inhibition of fungal growth by Ulva extracts, we next examined whether these extracts could elicit a mechanism of fruit defense response. While neither the ethanolic nor the acetonic extracts reduced the disease severity and incidence (Figure S2), ulvan extract induced the fruit's defense response and inhibited the 
disease progression. The concentration of $1000 \mathrm{mg} / \mathrm{L}$ was chosen for the ulvan extract based on previous publications as an optimum low-concentration, as higher concentrations of 5000-2000 mg/L [32,34] exhibited disease reduction and significant plant defense response similar to studies that used $1000 \mathrm{mg} / \mathrm{L}[13,35,36]$. Whereas a lower concentration of ulvan extract at $200 \mathrm{mg} / \mathrm{L}$ was not effective and did not induce oxidative burst in wheat cells [35].

To test the ability of ulvan extract to induce a defense response in table grapes, the grapes were dipped in $1000 \mathrm{mg} / \mathrm{L}$ ulvan extract two days before infection. While industry standards for disease treatment in table grapes do not usually include liquid submersion, we found this treatment to be optimal for testing proof-of-concept effects of ulvan extracts in the lab. The grapes treated with ulvan extract decreased decay compared to water-treated grapes, indicating induction of the fruit defense response mechanisms (Figure 2). Our results are supported by previous studies, which demonstrated that ulvan extract reduces anthracnose disease incidence caused by Colletotrichum gloeosporioides by $40 \%$ in papaya and $30 \%$ in apples, four days post-ulvan-treatment $[15,31]$.

It has been previously demonstrated that ulvan extract can induce both the systemic acquired resistance (SAR) and induced systemic resistance (ISR) systems and provide protection against fungal pathogens associated with either system, such as downy and powdery mildews - which are sensitive to salicylic acid-dependent defenses, and necrotrophic fungi such as B. cinerea - which are more sensitive to the jasmonic acid depended-defenses [37]. Moreover, after Medicago truncatula was treated with ulvan extract, an array of transcripts involved with defense response were upregulated [13]. One of the first lines of defense in the plant immunity response is the production of ROS. However, while the link between ROS generation and induced resistance to phytopathogens has been demonstrated [15], high levels of ROS can lead to faster fruit ripening and senescence, and even decay [38]. In the current study, ulvan-treated grapes display higher ROS levels at 2 and 4 DPT than water-treated grapes, indicating activation of defense-related pathways (Figure 3). To keep their cells from being oxidatively damaged, plants evolved ROS antioxidants enzymes such as SOD and CAT. Indeed, in our experimental setup, ulvan extract treatment increased SOD and CAT enzymatic activity (Figure 4). The increase in SOD and CAT enzymatic activity is consistent with [37]. While ulvan-treated grapes exhibited lower levels of total antioxidant at 2 and 4 DPT (Figure S3), some antioxidants (SOD, CAT) levels were higher than the control group. The hypothesis that ulvan may be able to downregulate certain enzymatic activities while upregulating others requires further studies to be undertaken.

As a result of defense response induction, a global defense response is activated including hundreds of genes. Chitinase and PAL are an example of two key enzymes in plant "defense response" to pathogenic stress [39-41]. Ulvan extract treatment increased chitinase activity 2 DPT (Figure 4). The increase in chitinase activity in response to the ulvan treatment could be explained by ulvan's structural similarity to phytopathogenic chitin monomers, which are secreted during the host-pathogen interaction leading to activation of pathogen-associated molecular patterns (PAMP) and ROS generation. However, the ulvan extract did not induce PAL activity. Polysaccharide extract depolymerized to oligo-ulvan had a higher PAL activity in tomato seedling leaves, but no activity was observed when the extract was de-sulfated [15]. The elemental analysis of our extract (Table 1) indicated low levels of sulfur compared to previously published data, which might explain the lack of increase in PAL activity. B. cinerea is known to tolerate high levels of ROS, however, it was inhibited after treatment with ulvan on fruit. Therefore, other fruit defense-related activities such as PAL, chitinase, and others are the probable cause of this fungal inhibition. In all, this study demonstrates that various extractions from Ulva rigida have no direct antifungal activity and only the thermochemical extraction of sulfated polysaccharides had an effect on the fruit defense response, which led to inhibition in decay development. Furthermore, this work lay down the basis for the ulvan extract mode of action to induce defense response.

To better characterize the ulvan extract, FT-IR spectra and the elemental analysis were performed and compared to published data. Those comparisons resulted in high 
similarity to other ulvan extraction and were shown to be within typical ranges of similar extractions (Figure 5 and Table 1). A high nitrogen content could correspond to both high protein content and non-protein nitrogenous substances, such as pigments, nucleic acids, and inorganic nitrogen. Importantly, the elemental analysis revealed that our nitrogen content was the lowest compared to other papers that analyzed the elemental constituents in ulvan extract (Table 1). We, therefore, infer that our aqueous extraction as ulvan extract is composed mostly of polysaccharides. However future studies that aim to test ulvan's defense-inducing capabilities should provide a more in-depth characterization of ulvan, such as its monosaccharidic profile, molecular weight, and level of sulfation in order to better characterize the most active component.

Since most biocontrol methods are well below 100\% efficacy, a single biocontrol approach will not meet commercial demands. Therefore, an integration of multiple methods may prove valuable and effective. Some compounded methods include combining fungicides with commercial sanitizers or salts, essential oils, altered atmosphere, plant elicitors, antagonistic organisms, and even physical methods such as temperature changes, radiation, pressure, and sonication. Many of these composite methods could have additive and even synergistic effects [42].

\section{Conclusions}

Ulva is a very common seaweed that was shown to have a wide range of agricultural and biomedical activities. This research tested the effect of several green seaweed Ulva rigida extracts on their efficacy in protecting harvested table grapes from the fungal pathogen $B$. cinerea. Our results show that ethanol and acetone-based extracts of Ulva rigida did not directly inhibit the conidia germination and fungal growth of $B$. cinerea, nor did they elicit an indirect inhibition effect by activating innate defense mechanisms in 'Scarlotta' table grapes.

While most of the previous studies focused on protecting growing crops, this study demonstrated that sulfated polysaccharides extracted from Ulva rigida (ulvan extract) reduced decay in harvested grapes by activating the fruit's defense response. The study of ulvan's mode of action in harvested fruit showed induction in various defense-related biomarkers as an increase in ROS and enzymatic activities of catalase, superoxide dismutase, and chitinase. The treatment did not affect fruit quality parameters such as the $\mathrm{pH}$, sugar levels, and the titratable acidity of the grapes. Therefore, Ulva rigida extract of sulfated polysaccharides has the potential to be used as a postharvest treatment to reduce decay development. Ulvan may be combined with other treatments in the future to achieve better decay control.

Supplementary Materials: The following supporting information can be downloaded at: https: / / www.mdpi.com/article/10.3390/foods11050723/s1, Table S1. Comparisons of peak wavenumber $(\tilde{V})$ values gathered from the FT-IR scan compared with peaks gathered from previously published data of ulvan extracts. Table S2. Changes in $\mathrm{pH}$ levels, sugar levels (Brix; TSS), titratable acidity. Figure S1. Ulva extracts promote in vitro growth of B. cinerea. Figure S2. Fungal growth on grapes treated with ethanolic or acetonic extracts. Figure S3. Total antioxidants in table grapes in response to ulvan treatment. References [43-47] are cited in the supplementary materials.

Author Contributions: Conceptualization, A.S., A.G. and N.A.; methodology, A.S., D.D.-A., O.G., A.G. and N.A.; software, A.S. and D.D.-A.; validation, A.S., D.D.-A. and N.A.; formal analysis, A.S. and D.D.-A.; investigation, A.S.; writing-original draft preparation, A.S.; writing-review and editing, A.S., D.D.-A., A.G. and N.A.; visualization, A.S., D.D.-A. and N.A.; supervision, A.G. and N.A. All authors have read and agreed to the published version of the manuscript.

Funding: This research received no external funding.

Institutional Review Board Statement: Not applicable.

Informed Consent Statement: Not applicable. 
Data Availability Statement: The datasets generated for this study are available on request to the corresponding author.

Conflicts of Interest: The authors declare no conflict of interest.

\section{References}

1. Dean, R.; Van Kan, J.A.; Pretorius, Z.A.; Hammond-Kosack, K.E.; Di Pietro, A.; Spanu, P.D.; Rudd, J.J.; Dickman, M.; Kahmann, R.; Ellis, J.; et al. The Top 10 fungal pathogens in molecular plant pathology. Mol. Plant. Pathol. 2012, 13, 414-430. [CrossRef] [PubMed]

2. Abbey, J.A.; Percival, D.; Abbey, L.; Asiedu, S.K.; Prithiviraj, B.; Schilder, A. Biofungicides as alternative to synthetic fungicide control of grey mould (Botrytis cinerea)—Prospects and challenges. Biocontrol Sci. Technol. 2019, 29, 207-228. [CrossRef]

3. Zhang, W. Global pesticide use: Profile, trend, cost/benefit and more. Proc. Int. Acad. Ecol. Environ. Sci. 2018, 8, 1-27.

4. Zhang, H.; Adwoa Serwah Boateng, N.; Legrand Ngolong Ngea, G.; Shi, Y.; Lin, H.; Yang, Q.; Wang, K.; Zhang, X.; Zhao, L.; Droby, S. Unravelling the fruit microbiome: The key for developing effective biological control strategies for postharvest diseases. Compr. Rev. Food Sci. 2021, 20, 4906-4930. [CrossRef] [PubMed]

5. Dwiastuti, M.E.; Soesanto, L.; Aji, T.G.; Devy, N.F.; Hardiyanto. Biological control strategy for postharvest diseases of citrus, apples, grapes and strawberries fruits and application in Indonesia. Egypt J. Biol. Pest. Control 2021, 31, 141. [CrossRef]

6. Kusstatscher, P.; Cernava, T.; Abdelfattah, A.; Gokul, J.; Korsten, L.; Berg, G. Microbiome approaches provide the key to biologically control postharvest pathogens and storability of fruits and vegetables. FEMS Microbiol. Ecol. 2020, 96, fiaa119. [CrossRef]

7. Romanazzi, G.; Sanzani, S.M.; Bi, Y.; Tian, S.; Martínez, P.G.; Alkan, N. Induced resistance to control postharvest decay of fruit and vegetables. Postharvest. Biol. Technol. 2016, 122, 82-94. [CrossRef]

8. Krishnamoorthi, R.; Sivakumar, S. Antifungal activity of seaweed Ulva lactuca extracted crude protein against pathogenic fungi. Asian J. Pharm. Clin. Res. 2019, 12, 393-396. [CrossRef]

9. Raj, G.A.; Chandrasekaran, M.; Jegan, S.; Venkatesalu, V. Phytochemical analysis and antifungal activity of Ulva Species from the kanniyakumari gulf of mannar, South Coast India. Nat. Prod. Ejbps 2017, 4, 9. [CrossRef]

10. Paulert, R.; Talamini, V.; Cassolato, J.E.F.; Duarte, M.E.R.; Noseda, M.D.; Paulert, R.; Stadnik, M.J. Effects of sulfated polysaccharide and alcoholic extracts from green seaweed Ulva fasciata on anthracnose severity and growth of common bean (Phaseolus vulgaris L.). J. Plant. Dis. Prot. 2009, 116, 263-270. [CrossRef]

11. Kidgell, J.T.; Magnusson, M.; de Nys, R.; Glasson, C.R.K. Ulvan: A systematic review of extraction, composition and function. Algal Res. 2019, 39, 101422. [CrossRef]

12. Beckers, G.J.M.; Spoel, S.H. Fine-tuning plant defence signalling: Salicylate versus jasmonate. Plant. Biol. 2006, 8, 1-10. [CrossRef]

13. Cluzet, S.; Torregrosa, C.; Jacquet, C.; Lafitte, C.; Fournier, J.; Mercier, L.; Salamagne, S.; Briand, X.; Esquerré-Tugayé, M.T.; Dumas, B. Gene expression profiling and protection of Medicago truncatula against a fungal infection in response to an elicitor from green algae Ulva spp. Plant. Cell. Environ. 2004, 27, 917-928. [CrossRef]

14. Jaulneau, V.; Lafitte, C.; Corio-Costet, M.F.; Stadnik, M.J.; Salamagne, S.; Briand, X.; Esquerré-Tugayé, M.T.; Dumas, B. An Ulva armoricana extract protects plants against three powdery mildew pathogens. Eur. J. Plant. Pathol. 2011, 131, 393-401. [CrossRef]

15. Abouraïcha, E.; El Alaoui-Talibi, Z.; El Boutachfaiti, R.; Petit, E.; Courtois, B.; Courtois, J.; El Modafar, C. Induction of natural defense and protection against Penicillium expansum and Botrytis cinerea in apple fruit in response to bioelicitors isolated from green algae. Sci. Hort. 2015, 181, 121-128. [CrossRef]

16. Chemodanov, A.; Robin, A.; Goldberg, A. Design of marine macroalgae photobioreactor integrated into building to support seagriculture for biorefinery and bioeconomy. Bioresour. Technol. 2017, 241, 1084-1093. [CrossRef]

17. Duanis-Assaf, D.; Galsurker, O.; Davydov, O.; Feygenberg, O.; Sagi, M.; Poverenov, E.; Fluhr, R.; Alkan, N. Double-stranded RNA targeting fungal ergosterol biosynthesis pathway controls Botrytis cinerea and postharvest grey mold. Plant. Biotechnol. J. 2021, 20, 226-237. [CrossRef]

18. Solairaj, D.; Ngea Guillaume Legrand, N.; Yang, Q.; Zhang, H.M. Isolation of pathogenic fungi causing postharvest decay in table grapes and in vivo biocontrol activity of selected yeasts against them. Physiol. Mol. Plant Pathol. 2020, 110, 101478. [CrossRef]

19. Galsurker, O.; Diskin, S.; Duanis-Assaf, D.; Doron-Faigenboim, A.; Maurer, D.; Feygenberg, O.; Alkan, N. Harvesting Mango Fruit with a Short Stem-End Altered Endophytic Microbiome and Reduce Stem-End Rot. Microorganisms 2020, 8, 558. [CrossRef]

20. Cheung, L.M.; Cheung, P.C.K.; Ooi, V.E.C. Antioxidant activity and total phenolics of edible mushroom extracts. Food Chem. 2003, 81, 249-255. [CrossRef]

21. Sudheeran, P.K.; Feygenberg, O.; Maurer, D.; Alkan, N. Improved cold tolerance of mango fruit with enhanced anthocyanin and flavonoid contents. Molecules 2018, 23, 1832. [CrossRef] [PubMed]

22. Bradford, M.M. A rapid and sensitive method for the quantitation of microgram quantities of protein utilizing the principle of protein-dye binding. Anal. Biochem. 1976, 72, 248-254. [CrossRef]

23. Assis, J.S.; Maldonado, R.; Muñoz, T.; Escribano, M.I.; Merodio, C. Effect of high carbon dioxide concentration on PAL activity and phenolic contents in ripening cherimoya fruit. Postharvest Biol. Technol. 2001, 23, 33-39. [CrossRef]

24. Abeles, F.B.; Bosshart, R.P.; Forrence, L.E.; Habig, W.H. Preparation and purification of glucanase and chitinase from bean leaves. Plant Physiol. 1971, 47, 129-134. [CrossRef] 
25. Beers, R.F.; Sizer, I.W. A spectrophotometric method for measuring the breakdown of hydrogen peroxide by catalase. J. Biol. Chem. 1952, 195, 133-140. [CrossRef]

26. Giannopolitis, C.; Ries, S. Superoxide dismutases: II. Purification and quantitative relationship with water-soluble protein in seedlings. Plant Physiol. 1977, 59, 315-318. [CrossRef]

27. Costa, C.; Alves, A.; Pinto, P.R.; Sousa, R.A.; Borges da Silva, A.; Rui, L.R.; Rodrigues, A.E. Characterization of ulvan extracts to assess the effect of different steps in the extraction procedure. Carbohydr. Polym. 2012, 88, 537-546. [CrossRef]

28. Del Rocío Quezada-Rodríguez, P.; Fajer-Ávila, J.E. The dietary effect of ulvan from Ulva clathrata on hematological-immunological parameters and growth of tilapia (Oreochromis niloticus). J. Appl. Phycol. 2017, 29, 423-431. [CrossRef]

29. Lahaye, M.; Robic, A. Structure and functional properties of ulvan, a polysaccharide from green seaweeds. Biomacromolecules 2007, 8, 1765-1774. [CrossRef]

30. Kitinoja, L.; Cantwell, M. Identification of appropriate postharvest technologies for improving market access and incomes for small horticultural farmers in Sub-Saharan Africa and South Asia. Acta Hort. 2010, 934, 31-40. [CrossRef]

31. Robin, A.; Chavel, P.; Chemodanov, A.; Israel, A.; Golberg, A. Diversity of monosaccharides in marine macroalgae from the Eastern Mediterranean Sea. Algal Res. 2017, 28, 118-127. [CrossRef]

32. Chiquito-Contreras, R.G.; Murillo-Amador, B.; Carmona-Hernandez, S.; Chiquito-Contreras, C.J.; Hernandez-Montiel, L.G. Effect of marine bacteria and ulvan on the activity of antioxidant defense enzymes and the bio-protection of papaya fruit against Colletotrichum gloeosporioides. Antioxidants 2019, 8, 580. [CrossRef]

33. Stadnik, M.J. Ulvan effect on conidial germination and appressoria formation of Colletotrichum gloeosporioides. Phytoparasitica 2014 42, 631-640. [CrossRef]

34. Rivas-Garcia, T.; Murillo-Amador, B.; Nieto-Garibay, A.; Chiquito-Contreras, R.G.; Rincon-Enriquez, G.; Hernandez-Montiel, L.G. Effect of ulvan on the biocontrol activity of Debaryomyces hansenii and Stenotrophomonas rhizophila against fruit rot of Cucumis melo L. Agronomy 2018, 8, 273. [CrossRef]

35. Paulert, R.; Ebbinghaus, D.; Urlass, C.; Moerschbacher, B.M. Priming of the oxidative burst in rice and wheat cell cultures by ulvan, a polysaccharide from green macroalgae, and enhanced resistance against powdery mildew in wheat and barley plants. Plant. Pathol. 2010, 59, 634-642. [CrossRef]

36. de Freitas, M.B.; Stadnik, M.J. Ulvan-induced resistance in Arabidopsis thaliana against Alternaria brassicicola requires reactive oxygen species derived from NADPH oxidase. Physiol. Mol. Plant Pathol. 2015, 90, 49-56. [CrossRef]

37. Dumas, B.; Jaulneau, V.; Lafitte, C.; Jacquet, C.; Fournier, S.; Salamagne, S.; Briand, X.; Esquerré-Tugayé, M.T. Ulvan, a sulfated polysaccharide from green algae, activates plant immunity through the jasmonic acid signaling pathway. J. Biomed. Biotechnol. 2010, 2010, 525291. [CrossRef]

38. Lacan, D.; Baccou, J.C. High levels of antioxidant enzymes correlate with delayed senescence in nonnetted muskmelon fruits Planta 1998, 204, 377-382. [CrossRef]

39. Saunders, J.; O'Neill, N. The characterization of defense responses to fungal infection in alfalfa. BioControl 2004, 49, 715-728. [CrossRef]

40. Muzzarelli, P.J.S.; Riccardo, A.A. Chitin and Chitinases; Birkhäuser Verlag: Boston, MA, USA, 1999; ISBN $3764358157 / 9783764358150$

41. Carver, T.L.W.; Robbins, M.P.; Zeyen, R.J.; Dearne, G.A. Effects of PAL-specific inhibition on suppression of activated defence and quantitative susceptibility of oats to Erysiphe graminis. Physiol. Mol. Plant Pathol. 1992, 41, 149-163. [CrossRef]

42. De Simone, N.; Pace, B.; Grieco, F.; Chimienti, M.; Tyibilika, V.; Santoro, V.; Capozzi, V.; Colelli, G.; Spano, G.; Russo, P. Botrytis cinerea and table grapes: A review of the main physical, chemical, and bio-based control treatments in post-harvest. Foods 2020, 9, 1138. [CrossRef] [PubMed]

43. Zhang, Z.; Wang, F.; Wang, X.; Liu, X.; Hou, Y.; Zhang, Q. Extraction of the polysaccharides from five algae and their potential antioxidant activity in vitro. Carbohydr. Polym. 2010, 82, 118-121. [CrossRef]

44. Toskas, G.; Hund, R.D.; Laourine, E.; Cherif, C.; Smyrniotopoulos, V.; Roussis, V. Nanofibers based on polysaccharides from the green seaweed Ulva rigida. Carbohydr. Polym. 2011, 84, 1093-1102. [CrossRef]

45. Thanh, T.T.; Quach, T.M.; Nguyen, T.N.; Luong, D.V.; Bui, M.L.; Van Tran, T.T. Structure and cytotoxic activity of ulvan extracted from green seaweed Ulva lactuca. Int. J. Biol. Macromol. 2016, 93, 695-702. [CrossRef]

46. Enrique, H.G.; Jose, A.Z.; Isai, P.R. Isolation and chemical characterization of algal polysaccharides from the green seaweed Ulva clathrata (Roth) C. Agardh. J. Appl. Phycol. 2011, 23, 537-542. [CrossRef]

47. Yaich, H.; Amira, A.B.; Abbes, F.; Bouaziz, M.; Besbes, S.; Richel, A.; Blecker, C.; Attia, H.; Garna, H. Effect of extraction procedures on structural, thermal and antioxidant properties of ulvan from Ulva lactuca collected in Monastir coast. Int. J. Biol. Macromol. 2017, 105, 1430-1439. [CrossRef] 